\title{
JOURNAL \\ OF \\ HELMINTHOLOGY
}

(Founded by R. T. LEIPER)

\author{
Edited by \\ J. J. C. BUCKLEY, D.Sc. \\ William Julien Courtauld Professor of Helminthology \\ in the University of London
}

\section{London School of Hygiene and \\ Tropical Medicine \\ Keppel Street \\ London \\ W.C.1}

